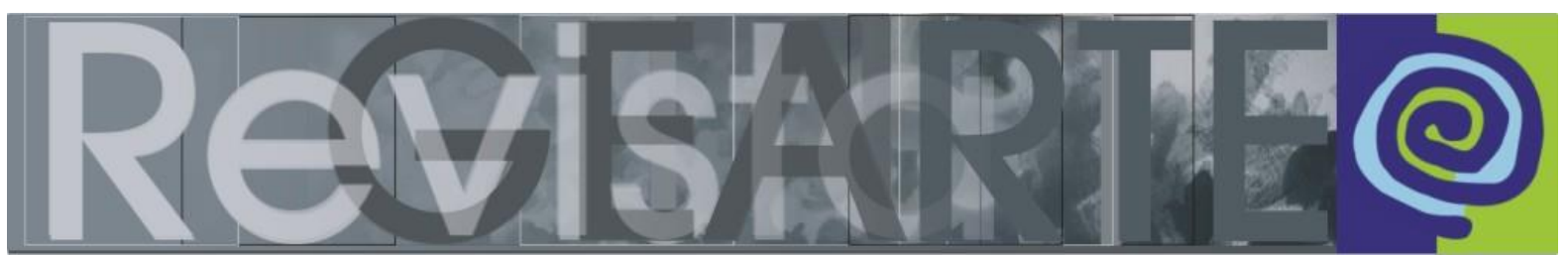

ISSN 2357-9854 | e-ISSN 2596-3198 (online)

\title{
A importância de Inalda Xavier para a constituição do patrimônio das artes visuais da UFRPE
}

\author{
Énery Gislayne de Sousa Melo \\ (Universidade Federal Rural de Pernambuco — UFRPE, Recife/PE, Brasil) \\ Julio Cesar Fernandes Vila Nova \\ (Universidade Federal Rural de Pernambuco - UFRPE, Recife/PE, Brasil) \\ Vera Conceição Alves Patello \\ (Universidade Federal Rural de Pernambuco — UFRPE, Recife/PE, Brasil) \\ Josimar Alves Monteiro \\ (Universidade Federal Rural de Pernambuco - UFRPE, Recife/PE, Brasil)
}

\begin{abstract}
RESUMO - A importância de Inalda Xavier para a constituição do patrimônio das artes visuais da UFRPE - Este artigo pretende destacar a importância da artista Inalda Xavier para a constituição do acervo das artes visuais da Universidade Federal Rural de Pernambuco, identificado através de um processo de catalogação de artes realizado pelo projeto "Artes Visuais da UFRPE: revelações identitárias a partir do patrimônio artístico-histórico", no período de fevereiro a maio de 2019. Apresentamos um painel sobre a história das artes visuais de Pernambuco, especificamente, do período em que Inalda fez parte, destacando a sua contribuição para o campo das artes de Pernambuco e identificamos a influência da artista sobre a construção do patrimônio artístico visual da universidade.
\end{abstract}

\section{PALAVRAS-CHAVE}

Artes visuais. Inalda Xavier. UFRPE. Oficina Guaianases. Litogravura.

ABSTRACT - The importance of artist Inalda Xavier for the Universidade Federal Rural de $f$ Pernambuco's collection of Visual Arts - This paper highlights the importance of artist Inalda Xavier for the Federal Rural University of Pernambuco's collection of visual arts, catalogued within the project "Artes Visuais da UFRPE: revelações identitárias a partir do patrimônio artístico-histórico" (UFRPE Visual Arts: Identity Revelations from its Artistic and Historic Patrimony), developed between February and May 2019. We present an overview of the history of the visual arts of Pernambuco, specifically of the period in which Inalda was part. We highlight the artist's contribution to the field of arts in Pernambuco and indicate her influence on the construction of the University's visual artistic collection.

\section{KEYWORDS}

Visual arts. Inalda Xavier. UFRPE. Oficina Guaianases. Lithography.

RESUMEN - La importancia de Inalda Xavier para la constitución del patrimonio de las artes visuales en la UFRPE - Este artículo pretende resaltar la importancia de la artista Inalda Xavier para la constitución de la colección de artes plásticas de la Universidad Federal Rural de Pernambuco, identificada a través de un proceso de catalogación de artes realizada por el proyecto "Artes visuales en la UFRPE: revelaciones identitarias del patrimonio histórico-artístico", de febrero a mayo de 2019. Presentamos un panel sobre la historia de las artes plásticas en Pernambuco, en concreto, del período en el que Inalda participó, destacando su contribución al campo de las artes en Pernambuco e identificamos la influencia de la artista en la construcción del patrimonio artístico visual de la Universidad. PALABRAS CLAVE

Artes visuales. Inalda Xavier. UFRPE. Taller de Guaianases. Litografía.

MELO, Énery Gislayne de Sousa; VILA NOVA, Julio Cesar Fernandes; PATELLO, Vera Conceição Alves; MONTEIRO, 


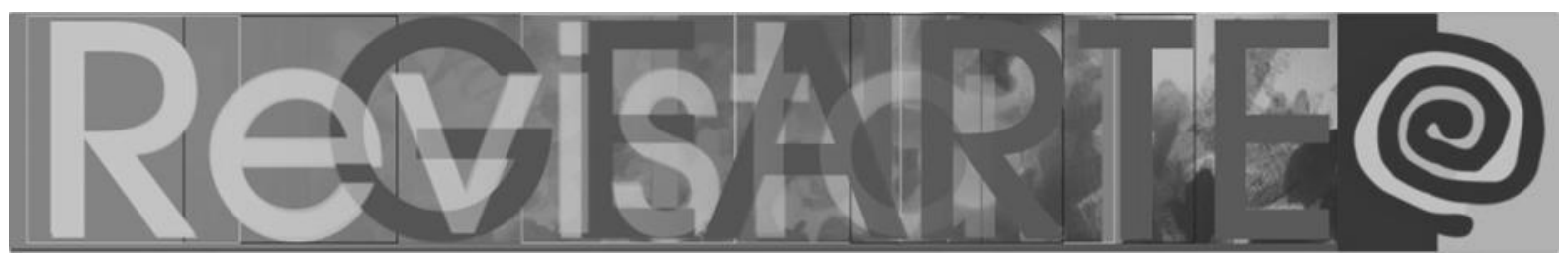

\section{Introdução}

A Universidade Federal Rural de Pernambuco (UFRPE) é uma instituição centenária, com fundação datada no ano de 1912. Seu campus-sede está situado no bairro de Dois Irmãos, subúrbio do Recife, capital de Pernambuco. Por ocasião das comemorações pela passagem dos seus cem anos, em 2012, uma das imagens mais recorrentes, nos convites e materiais de divulgação, foi o painel do artista plástico Lula Cardoso Ayres que ambienta o Salão Nobre do prédio da Reitoria. O painel, pintado em 1957, retrata o campo e áreas geográficas do estado, com cenas ligadas à agricultura e à pecuária.

Trata-se de uma obra que reflete o contexto sócio-histórico de atuação da instituição naquele período, quando a então denominada Universidade Rural de Pernambuco (URP) se destacava pelo desenvolvimento dos cursos de Agronomia e de Medicina Veterinária (MARTINS; LEITÃO, 2009), tendo incorporado também, através da Lei Estadual № 1.837, de 17 de março de 1954, o curso de Economia Doméstica Rural e a Escola Agrotécnica de São Lourenço da Mata.

Considerando, com Belting (2012) e Bertello (2004), que uma obra de arte contribui para a descoberta de si e do outro, podendo também revelar papéis da representação da identidade cultural e histórica de uma época ou entidade, passamos a refletir sobre como a significativa ampliação da UFRPE para outras áreas do conhecimento repercutiu em termos das representações artísticas dedicadas à instituição ao longo desse tempo. De fato, a história da UFRPE na segunda metade do século XX e nas primeiras décadas do XXI marca a ampliação da oferta de novos cursos na modalidade presencial e à distância, em áreas do conhecimento bastante diversas, como Computação, Ciências Humanas, Ciências Aplicadas, Engenharias e licenciaturas em diversas áreas. Além disso, a universidade ampliou sua presença em regiões mais afastadas da capital pernambucana, passando a atuar em cidades do interior do estado, sobretudo a partir da consolidação do Programa de Reestruturação e Interiorização das 


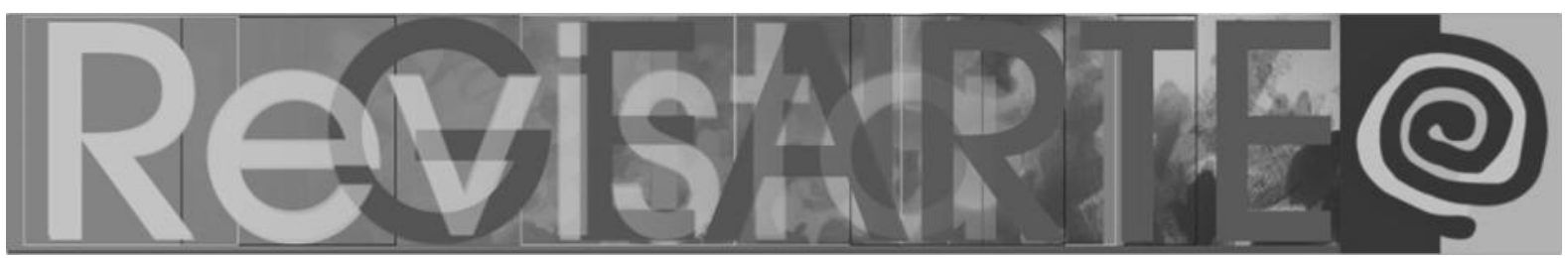

universidades, no governo Lula, quando a UFRPE se expandiu para o Agreste, com a Unidade Acadêmica de Garanhuns (UAG), e o Sertão, com a Unidade Acadêmica de Serra Talhada (UAST).

Entre os novos cursos, destacamos a criação dos primeiros cursos de Artes da UFRPE, ofertados na modalidade à distância pela Unidade Acadêmica de Educação a Distância e Tecnologia (UAEADTec). O curso de Licenciatura em Artes Visuais, com ênfase em digitais, criado em 2010, foi o primeiro na modalidade à distância oferecido no Brasil (UFRPE, 2019). E, atendendo a uma demanda dos estudantes formados nesse curso, associada a uma carência de formação específica para os professores do estado e do município da área de ensino de artes foi criado, em 2013, o curso de especialização em Artes e Tecnologias da UAEADTec (UFRPE, 2018).

Essa nova comunidade de acadêmicos, professores e estudantes de áreas do conhecimento e localizações distintas, tem provocado um redesenho do perfil da universidade, tema que deu origem, em 2019, ao projeto de pesquisa denominado "Artes Visuais da UFRPE: revelações identitárias a partir do patrimônio artísticohistórico". O projeto visa à catalogação da produção artística dedicada à UFRPE, analisando como se dá a representação da universidade nas obras enfocadas. Algumas perguntas motivadoras surgiram na etapa inicial da pesquisa, como motes para a investigação, a saber: como seria a tela pintada por Lula Cardoso Ayres no contexto atual? Quais outros artistas contribuíram para a representação da imagem dessa universidade? Como ela foi representada por eles?

O processo de catalogação das obras da UFRPE foi iniciado em fevereiro de 2019. Serviu-nos de inspiração o projeto Recife Arte Pública, que identificou, nos anos de 2015 e 2016, mais de duzentas esculturas em locais públicos e setenta murais em espaços públicos ou privados com acesso ao público, como bancos, museus e outras instituições situadas na capital pernambucana. Entre os artistas identificados nesse projeto, destacam-se Cícero Dias, Abelardo da Hora, 


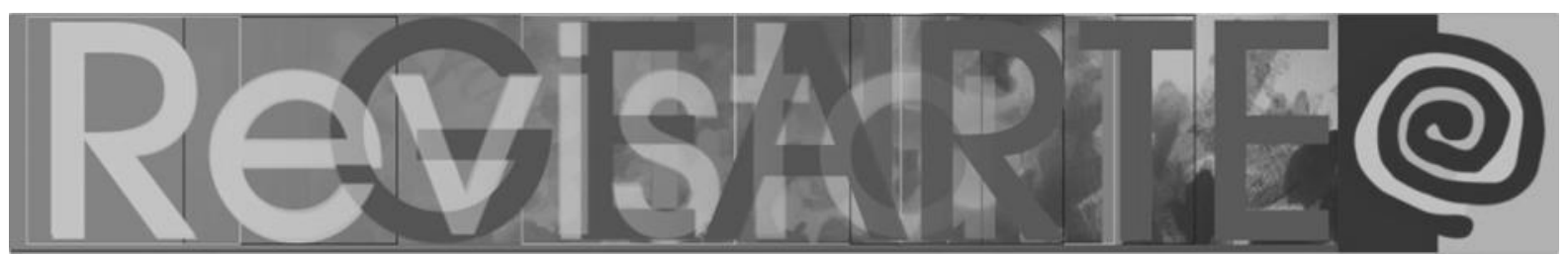

Francisco Brennand, Corbiniano Lins e Lula Cardoso Ayres (CARDOSO; SANTOS; TORRES, 2017). A UFRPE está presente no acervo digital por meio do painel de Lula Cardoso Ayres, mencionado acima, e também por uma obra, datada de 1978, de autoria de Inalda Xavier, artista sobre a qual nos debruçamos aqui.

O trabalho de Inalda Xavier é um painel entalhado em madeira, localizado no prédio Otávio Gomes, do Departamento de Agronomia. Sem título, medindo doze metros de comprimento e 2,65 metros de altura, a obra é uma das mais importantes do acervo de artes visuais (painéis, murais e esculturas) catalogado pela equipe do projeto da UFRPE. Retrata cenas do sertão nordestino, com destaque para a forte presença de figuras femininas, e detalhes retratando árvores e pássaros. Na fase de estudo sobre a autora, identificamos que a artista foi professora da universidade. Essa descoberta suscitou vários questionamentos, principalmente porque o seu painel, sendo uma das obras mais marcantes do levantamento, considerando suas dimensões, riqueza de detalhes, qualidade estética e relevância temática, não tem uma divulgação mais efetiva na universidade.

A descoberta fez aflorar a curiosidade sobre a pessoa de Inalda Xavier, sua trajetória artística e profissional como professora da casa: ela teria exercido a docência em qual curso/departamento? Qual a sua projeção como artista plástica em Pernambuco? A universidade reconhecia essa projeção? Por qual motivo a obra da artista está localizada especificamente naquele prédio? Existiriam outras obras de Inalda na universidade? Diante de todos esses questionamentos, parte dos pesquisadores do projeto Artes da UFRPE voltou a sua atenção para investigar essa personagem, sua relevância no panorama artístico de Pernambuco, sua atuação docente na universidade e sua contribuição para o desenvolvimento do patrimônio artístico e cultural da UFRPE. Este artigo expõe parte dos resultados preliminares dessa investigação, tendo como objetivo compreender a relevância de Inalda Xavier para a constituição do patrimônio artístico visual da UFRPE. 


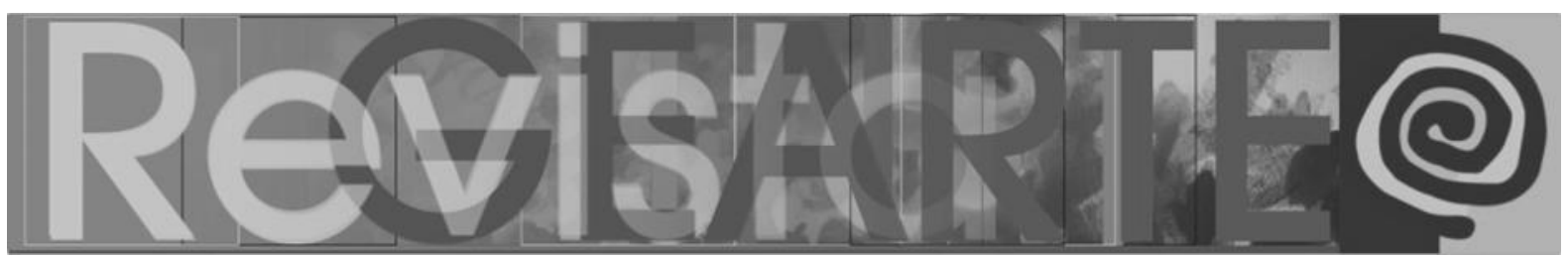

A metodologia de coleta de dados consistiu em pesquisa bibliográfica e documental (catálogos de exposições, certificados de cursos, entre outros), bem como entrevistas não diretivas (THIOLLENT, 1988) com pessoas que conviveram com Inalda: ex-alunas e colegas professores da universidade, familiares e outros artistas. Os dados foram triangulados e nos permitiram identificar que Inalda trabalhava com várias linguagens artísticas, destacando-se, entretanto, pela litogravura, técnica de gravação do desenho em pedra, para impressão. A partir do trabalho com essa técnica, a autora participou dos principais movimentos da história da arte de Pernambuco, principalmente da Oficina Guaianases de Gravura, criada por João Câmara, em 1974. Essas e outras informações são apresentadas de forma mais detalhada a seguir, com um relato descritivo sobre a artista e professora, e a sua relação com a construção do patrimônio artístico da instituição pesquisada.

\section{Breve histórico das artes visuais em Pernambuco: da Escola de Artes (1932) à Oficina Guaianases (1995)}

Neste trabalho, não se pretende apresentar um estudo denso sobre a história das artes visuais de Pernambuco. Limitamo-nos a discutir alguns eventos que podem ajudar a situar a participação e importância de Inalda Xavier nesse cenário. Nosso recorte tem como início a formação da Escola Belas Artes de Pernambuco, em 1932, indo até o período de criação e funcionamento da Oficina Guaianases de Gravuras, de 1974 a 1995.

A Escola de Belas Artes de Pernambuco foi criada em 1932, como resultado do engajamento dos artistas plásticos Álvaro Amorim, Bibiano Silva, Mário Nunes, Balthazar da Câmara, Mário Túlio e Murilo La Greca. O objetivo da escola era instruir jovens artistas com conhecimentos, inicialmente nas áreas de arquitetura, pintura e escultura (RIBEMBOIM; SOUZA, 2014). Era frequentada pelos principais artistas da época, a exemplo de Abelardo da Hora. No final da década de 1940, a Escola foi incorporada à Universidade Federal de Pernambuco, sendo extinta em 1976 para 


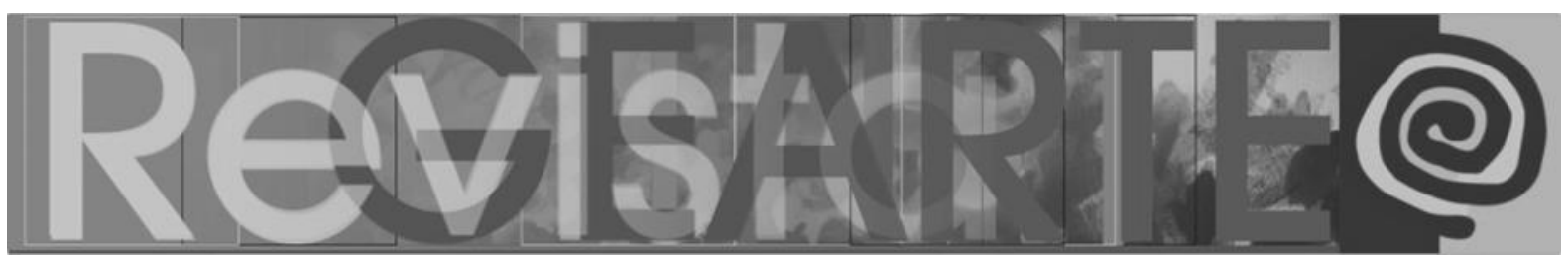

juntar-se à Faculdade de Arquitetura, ao Departamento de Letras e ao curso de Biblioteconomia da UFPE, formando o Centro de Artes e Comunicação. O endereço onde funcionou desde a época de sua criação, rua Benfica, número 150, no bairro da Madalena, hoje abriga o Centro Cultural Benfica, também ligado à UFPE.

Ainda na década de 1930, em oposição ao ensino de cunho acadêmico proposto pela Escola de Belas Artes, foi organizado, no Recife, o Grupo Independentes, formado por artistas como Vicente do Rêgo Monteiro, Cícero Dias, Lula Cardoso Ayres, Percy Lau, Hélio Feijó, Eliezer Xavier, entre outros. Uma das principais críticas desse grupo à escola consistia na ênfase dada às referências de estilos e temas advindos da Europa e ao ensino excessivamente técnico. O grupo defendia que fossem explorados temas nacionais e regionais e que houvesse uma abertura para o processo de criação de novos estilos e experimentações. Telles Junior era um dos artistas da Escola que representava uma exceção às influências temáticas externas e é citado como um dos pioneiros a pintar paisagens de Pernambuco, seu povo e suas casas (RIBEMBOIM; SOUZA, 2014).

Com o objetivo de fortalecer o universo dos artistas e favorecer a comercialização das artes, em 1948, vários artistas, liderados por Abelardo da Hora, Hélio Feijó e Ladjane Bandeira, juntaram-se e formaram a Sociedade de Arte Moderna (SAM), que funcionou, em um primeiro momento, no primeiro andar do prédio de número 35 da rua Imperatriz, no bairro da Boa Vista, Centro do Recife. Da SAM fizeram parte artistas como Lula Cardoso Ayres, Francisco Brennand, Aloísio Magalhães, Reynaldo Fonseca, Gilvan Samico e os irmãos, Wellington Virgolino e Wilton de Souza (CLÁUDIO, 2010).

Uma das iniciativas mais importantes da SAM foi a criação, em 1952, de um espaço de convivência e formação para o desenvolvimento dos trabalhos dos artistas, que foi denominado Atelier Coletivo. O Atelier funcionou até 1957, e inicialmente estava instalado na casa de Abelardo da Hora. Os artistas lá se reuniam, discutiam sobre arte e produziam suas obras, com todo o material 


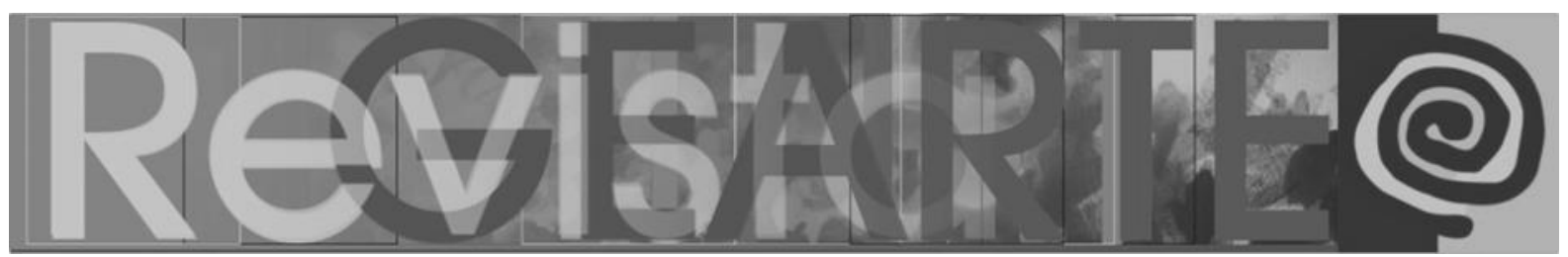

adquirido por meio de cota entre os artistas. Contudo, a maioria deles não tinham recursos para contribuir de forma permanente ou significativa, e por isso o Atelier estava sempre em dificuldades financeiras. Uma das estratégias adotadas para angariar recursos para a SAM foi a criação do Clube da Gravura, que mantinha intercâmbio com um grupo do Rio Grande do Sul, liderado por Carlos Scliar. Essa aproximação foi muito importante para os artistas pernambucanos, pois propiciou a realização de várias exposições, inclusive internacionais, facilitando a venda das gravuras não só em Pernambuco, mas no Brasil todo e em outros países. A partir dessas e de outras ações o Atelier Coletivo alcançou prestígio no cenário cultural do Recife, seus artistas participaram de mostras em vários países da Europa, China, União Soviética, Israel, Argentina e Mongólia (CLÁUDIO, 2010).

Em 1960, durante a primeira gestão de Miguel Arraes na Prefeitura do Recife, Abelardo da Hora assumiu várias funções no governo, como a de diretor da Divisão de Parques e Jardins, secretário de Educação e diretor da Divisão de Artes Plásticas e Artesanato. Durante sua gestão como diretor da Divisão de Artes Plásticas e Artesanato fundou, ainda em 1960, o Movimento de Cultura Popular (MCP), que tinha como objetivo elevar o nível cultural do povo e de incentivar, de um modo geral, a educação, abrangendo não somente as artes plásticas, mas também a música, a dança e o teatro (SOUZA, 2014). Participaram do MCP intelectuais e artistas como Francisco Brennand, Ariano Suassuna, Hermilo Borba Filho, entre tantos outros. O MCP funcionou, inicialmente, em uma galeria ao lado da agência central dos Correios na avenida Guararapes, depois passou a ter sede própria no Sítio da Trindade, no bairro de Casa Amarela, que foi transformado em um local para articulação e abrigo de eventos artísticos, culturais e educacionais. O movimento foi extinto em 1964, depois que tanques de guerra do exército ocuparam o gramado do sítio (GASPAR, 2009), em decorrência do golpe de Estado que instaurou a ditadura civil-militar no Brasil.

Ainda em 1960, houve uma grande conquista para os artistas, a partir da aprovação, pela Câmara Municipal do Recife, da Lei ำ 7.427, que previa a

MELO, Énery Gislayne de Sousa; VILA NOVA, Julio Cesar Fernandes; PATELLO, Vera Conceição Alves; MONTEIRO, 72 Josimar Alves. A importância de Inalda Xavier para a constituição do patrimônio das artes visuais da UFRPE.

Revista GEARTE, Porto Alegre, v. 8, n. 1, p. 66-92, jan./abr. 2021.

Disponível em: http://seer.ufrgs.br/gearte 


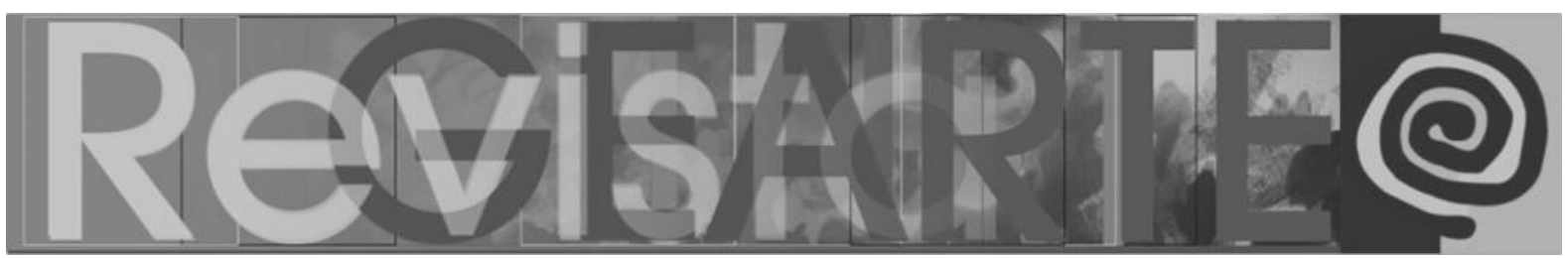

instalação de obras de artes visuais nos edifícios de grande porte no Recife. De acordo com o artigo 950 da lei:

\begin{abstract}
Em todo edifício que vier a ser construído no Município do Recife, deverão constar obras originais de valor artístico, as quais farão parte integrante deles.

$\S 1$ 1 Os efeitos do artigo anterior incidirão sobre:

1 - todos os prédios com área superior a $2.000 \mathrm{~m}^{2}$ (dois mil metros quadrados) e bem assim os de grande concentração pública, tais como; casas de Espetáculos, Hospitais, Casas de Saúde, Colégios ou Escolas Públicas, Estações de Passageiros, Estabelecimentos Bancários, Hotéis, Estádios, Clubes Esportivos, Sociais ou Recreativos que tenham áreas superior a $1.000 \mathrm{~m}^{2}$ (mil metros quadrados).

$\S 2^{\circ}$ Ficam isentos dos efeitos deste artigo as residências particulares. $\S 3$ №̃a será concedido à construção o competente "Habite-se" quando na mesma não constar a obra de arte exigida neste Código, cuja maquete deverá ser aprovada pela Prefeitura Municipal do Recife, com o visto do Autor do Projeto da Arquitetura, do Proprietário e assinatura do autor da Obra de Arte.

$\S 4^{\circ}$ Somente poderão executar os serviços referidos no parágrafo anterior os artistas previamente inscritos na Prefeitura Municipal do Recife (RECIFE, 1962).
\end{abstract}

Essa lei foi extremamente importante para a difusão e valorização das artes. Para sua implantação foi criada a Comissão de Artes Plásticas do Município do Recife, vinculada à Prefeitura, cujas funções prioritárias eram credenciar artistas pernambucanos e julgar os trabalhos artísticos a serem instalados nos prédios. A comissão era composta por representantes da Escola de Belas Artes, do Movimento de Cultura Popular, da Sociedade de Arte Moderna, entre outras representações dos órgãos da área da arquitetura e da construção civil (AABB, 1963).

Atualmente, está em vigor a Lei de número 16.292, de 1997, que regulamenta as atividades de edificações e instalações no município do Recife. Em sua seção IV, artigo 17, ela enumera os profissionais que podem projetar obras de arte para edificações, sendo eles: 0 arquiteto, arquiteto urbanista, desenhista industrial, comunicador visual e o artista plástico. Além disso, no seu artigo 129, determina que "toda edificação, com área igual ou superior a $1000 \mathrm{~m}^{2}$ deverá conter, em lugar de destaque, obra de arte executa em escultura, pintura, mural ou relevo escultórico" (RECIFE, 1997).

MELO, Énery Gislayne de Sousa; VILA NOVA, Julio Cesar Fernandes; PATELLO, Vera Conceição Alves; MONTEIRO, 73 Josimar Alves. A importância de Inalda Xavier para a constituição do patrimônio das artes visuais da UFRPE.

Revista GEARTE, Porto Alegre, v. 8, n. 1, p. 66-92, jan./abr. 2021.

Disponível em: http://seer.ufrgs.br/gearte 


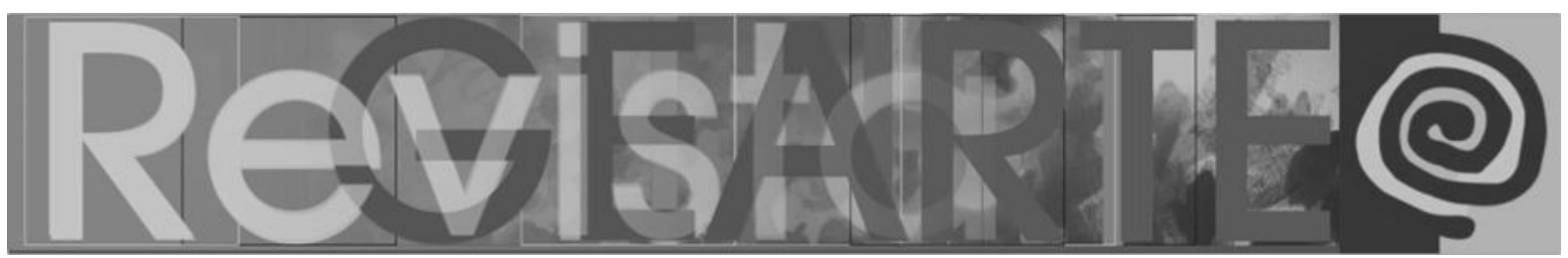

Outra iniciativa de fortalecimento da comunidade de artistas plásticos do estado foi a criação, em 1968, da Associação de Artistas Plásticos Profissionais de Pernambuco (AAPPE), com o objetivo de criar uma unidade de reivindicação dos artistas (BRITO NETO, 2016). A AAPPE era formada por artistas de diversos setores, como pintores, gravuristas, escultores, entre outros. A sua criação foi resultado dos movimentos de organização coletiva dos artistas firmados nas décadas anteriores, a exemplo da Sociedade de Arte Moderna do Recife.

Para fazer parte da associação o artista precisava comprovar participação em pelo menos três exposições coletivas ou uma individual. Durante seus trinta anos de funcionamento, a associação teve cerca de cem associados, que contavam com apoio para a venda de suas produções, além de outras iniciativas no âmbito da carreira profissional. A gestão da AAPPE contou com artistas como Josael de Oliveira e Silva, Wellington Virgolino, Aluísio Braga, Teresa Carmem, Delano, Wilton de Souza, e como conselheiros, Francisco Brenannd, João Câmara, Gilvan Samico, Maria Carmem, Abelardo Rodrigues, entre outros (BRITO NETO, 2016).

A AAPPE funcionou durante trinta anos, entre 1968 e 1998. Ao longo desse período, suas principais ações foram: a fiscalização do atendimento à lei municipal que obrigava edifícios de grande porte a ter uma obra de arte em local de ampla visibilidade; a intermediação da venda da obra de artistas para as construtoras; a realização do concurso para ilustração do Bilhete da Loteria Federal de 1973 e para a capa da Lista telefônica da cidade do Recife; e a articulação para a organização de exposições nacionais e internacionais (BRITO NETO, 2016).

Mais tarde, em 1974, foi criada a Oficina Guaianases de Gravura, por iniciativa de João Câmara e Delano, funcionando até 1995. No início, o seu endereço foi o ateliê de João Câmara, localizado no bairro de Campo Grande, na rua Guaianases, origem do nome da Oficina. Todos os sábados, um grupo de artistas se reunia no local para produzir suas litogravuras. A oficina funcionou nesse 


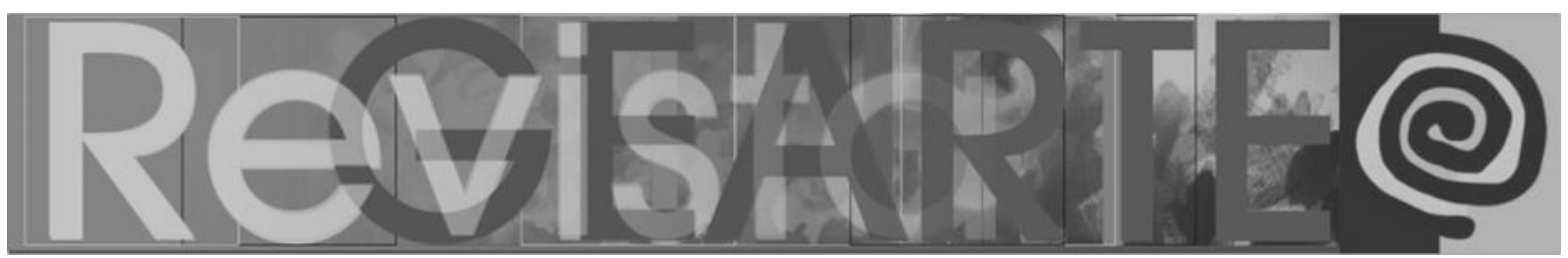

endereço até 1979, depois mudou-se para o Mercado da Ribeira, em Olinda, mantendo-se lá até o encerramento das suas atividades, em 1995. No mercado, a Oficina Guaianases tinha como objetivo não apenas servir de local para a produção de litogravura, mas também como espaço para realização de exposições e cursos, muitas vezes ministrados por João Câmara e Delano (RIBEMBOIM; SOUZA, 2014).

Participaram da Oficina Guaianases vários artistas plásticos de diferentes localidades, entre os quais destacamos Gilvan Samico, Guita Charifker, Gil Vicente, Humberto Carneiro, Thereza Carmem, Luciano Pinheiro, José Carlos Viana, Tereza Costa Rego, Raul Córdula, Romero de Andrade Lima, Maria Carmen, Maurício Arraes, Maurício Silva, Liliane Dardot, Inalda Xavier, Isa Pontual, Jeanine Uchoa, José de Moura, Petrônio Cunha, José de Barros José Paulo, José Carlos Xavier, Maria Tomaselli, Mário Ricardo, Marisa Lacerda, Marisa Varella, Rinaldo, Francisco Neves, José Cláudio (CLÁUDIO, 2010).

Em 1995, depois do encerramento das atividades da Oficina Guaianases, todo o material foi cedido à UFPE, que recentemente fez um trabalho de catalogação e de disponibilização do acervo através do site Coleção História da Oficina Guaianases de Gravuras. O acervo reúne mais de 2 mil litogravuras e 2.345 impressos, os quais estão sob a guarda do Departamento de Teoria da Arte, armazenados no Laboratório Oficina Guaianases de Gravura, localizado na Biblioteca Joaquim Cardozo (CARVALHO; OTERO; BARBOSA, 2006).

No tocante à participação de Inalda Xavier nos movimentos e coletivos mencionados, a artista teve presença mais ativa no Movimento de Cultura Popular e na Oficina Guaianases, tendo oportunidade de conviver com os grandes artistas reconhecidos de Pernambuco. Além disso, sua formação artística deu-se na Escola de Belas Artes. Sobre esses fatos, apresentamos uma discussão em uma seção mais adiante. 


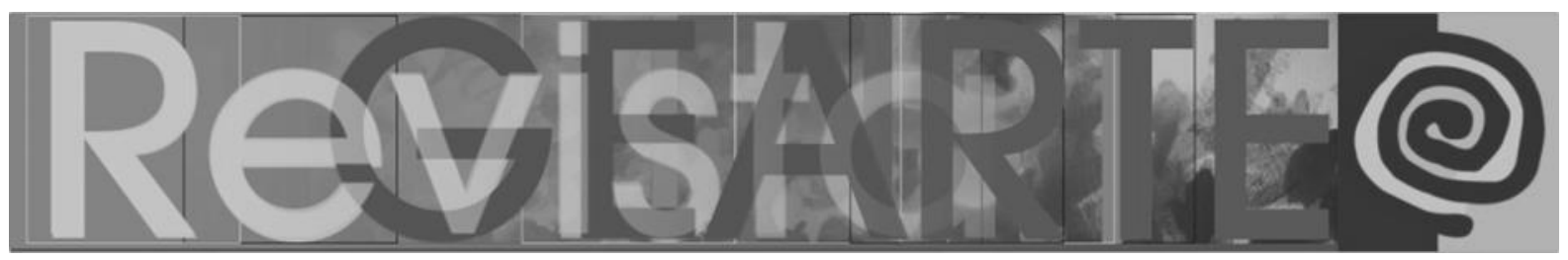

\section{Metodologia}

Esta investigação é qualitativa, já que busca uma compreensão mais profunda do objeto de pesquisa e entende que a visão de mundo do pesquisador, o contexto e história do objeto investigado interferem nas interpretações e significados atribuídos (CHIZZOTTI, 2010). A etapa de coleta de dados que deu origem a este artigo teve como instrumentos: catalogação das obras de artes visuais (murais, painéis, esculturas e bustos) da UFRPE; pesquisa bibliográfica e documental sobre os artistas e as obras; entrevistas não diretivas, especificamente sobre Inalda Xavier. A entrevista não diretiva tem como característica a coleta de informações por meio do discurso livre do entrevistado (THIOLLENT, 1988).

\section{$1^{\text {a }}$ etapa - Catalogação das artes visuais da UFRPE}

Esta etapa foi realizada no período de fevereiro a maio de 2019. Foram visitados cerca de quinze prédios apontados pelo setor de Engenharia e Infraestrutura da universidade e de outros servidores da UFRPE como locais em que havia obras de artes. Os investigadores catalogaram as obras por meio de uma ficha catalográfica, com registro fotográfico, acompanhado do título da obra, autor, ano e localidade. Foi nessa etapa que se identificou o painel talhado em madeira de autoria de Inalda Xavier, a partir de uma indicação do professor Mateus Ribeiro Rosas Filho, ex-diretor do Departamento de Agronomia.

\section{$2^{\underline{a}}$ etapa - Pesquisa bibliográfica e documental sobre as obras e os artistas}

Foi realizada uma investigação sobre os artistas e as obras localizados na fase de catalogação. A investigação utilizou pesquisa bibliográfica e documental, na base de dados da web, utilizando-se o recurso de busca por meio de palavraschave como o nome da artista e da obra. Além disso, foram entrevistadas pessoas da universidade com conhecimentos sobre a obra e a artista, como, por exemplo, servidores da Biblioteca Central que conheciam um pouco da história do acervo localizado em seu prédio. 


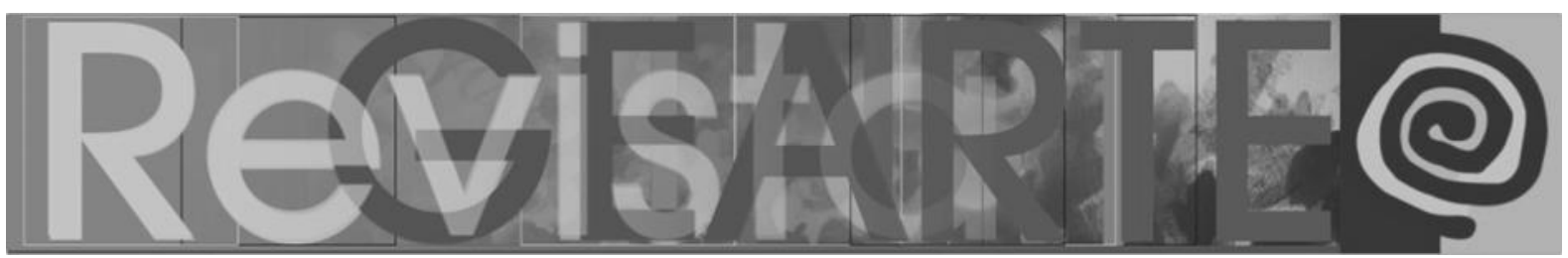

Nesta etapa, identificamos, através de uma notícia publicada no site da UFRPE no dia 29 de junho de 2017, que Inalda Xavier havia sido professora da universidade, "A docente era vinculada ao Departamento de Ciências Domésticas e, também, ao Colégio Agrícola Dom Agostinho lkas (Codai), onde foi professora de Artes".

Tendo em vista o fato de que a artista foi professora da universidade e considerando o valor artístico de sua obra segundo o grupo de pesquisadores, decidiu-se investigar a trajetória artística de Inalda Xavier, para verificar a sua participação no cenário artístico de Pernambuco e sua importância para a constituição do acervo da UFRPE.

\section{$3^{a}$ etapa - Entrevista não diretiva sobre Inalda Xavier}

Nessa fase, ao trabalho de pesquisa na internet e ao estudo bibliográfico e documental (catálogos de exposições, recortes de jornais, certificados de cursos, livros entre outros) foram somadas entrevistas não diretivas com pessoas que conheceram Inalda, a exemplo de ex-alunas e colegas professoras da universidade, além de familiares e artistas.

A partir do contato com familiares da artista obtivemos informações sobre a trajetória artística de Inalda. A seguir apresentamos os principais documentos que serviram de base de dados para esta pesquisa.

1. Livros: Memória do Atelier Coletivo/Artistas de Pernambuco/Tratos da arte de Pernambuco (CLÁUDIO, 2010) e Boa Vista: berço das artes plásticas pernambucanas (RIBEMBOIM; SOUZA, 2014);

2. Revista da $A A B B$, Recife, volume 3, número 9, 1963;

3. Versões do currículo, de diferentes épocas, elaborados pela própria artista;

4. Cartas de apresentação da artista elaboradas por Corbiniano Lins, em diferentes épocas; 


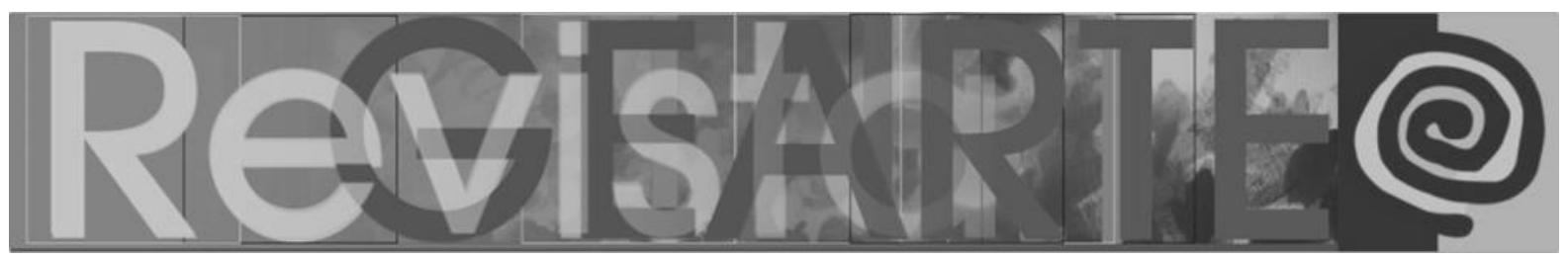

5. Catálogos de exposições;

6. Recortes de jornais.

Os dados coletados foram triangulados para fins de construção de um relato descritivo sobre a artista e sua importância para a história da arte de Pernambuco. Em relação ao acervo da universidade, buscou-se identificar elementos que demonstrem a participação de Inalda em sua elaboração. Na seção seguinte, descrevemos esse acervo e discutimos a sua constituição.

\section{Sobre a artista Inalda Xavier}

Inalda da Silva Xavier (1930 - 2017) é o nome de registro da artista, que identificava suas obras pela sigla IX, de Inalda Xavier. Sua trajetória demonstra uma personalidade de vanguarda em ideias e ações, obcecada pela arte, detalhista e perfeccionista em sua produção. Depoimentos e relatos atestam como traços de sua personalidade a modéstia e simplicidade extremadas, mas ao mesmo tempo um gosto requintado e delicado, que compartilhava com todos ao seu redor. No quadro geral que pudemos compor a respeito da personalidade e atuação da artista, acrescentam-se, ainda, a generosidade com seus alunos e alunas, além da constituição de laços afetivos muito fortes com a família e amigos.

Ela nasceu em Jaboatão dos Guararapes, enquanto sua mãe visitava a cidade, mas viveu toda a sua vida no Recife. De acordo com depoimentos da família, desde pequena ela já gostava de desenhar: "Ela costumava fazer caricaturas dos professores e sempre era chamada para ajudar na ornamentação das festas da escola" (depoimento de Ivanise, irmã da artista). Formou-se no curso de graduação em Professorado de Desenho, em 1961, pela Escola de Belas Artes da Universidade Federal de Pernambuco. O seu diploma é assinado pelo artista plástico Murillo La Greca, diretor daquela escola na época. Em 1974, realizou seu mestrado nos Estados Unidos, obtendo o título de Mestra em Ciências pela New Mexico State University. 


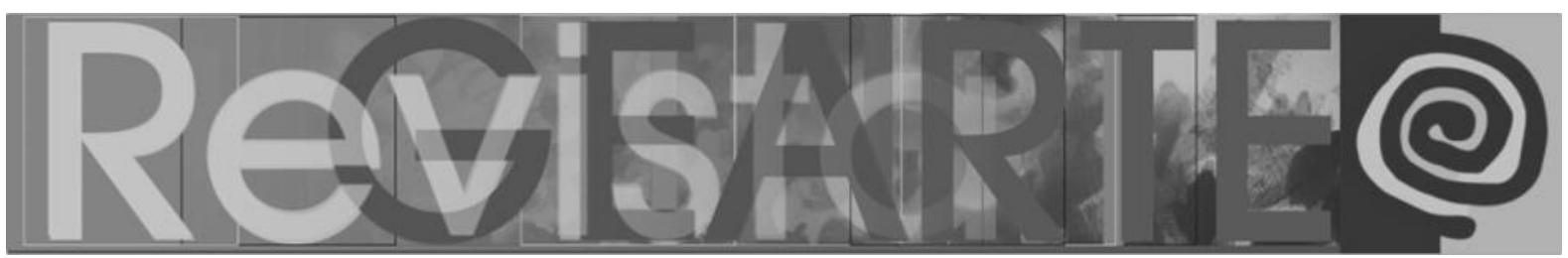

Inalda sempre teve como profissão o ensino de artes. Fez parte do quadro efetivo da rede estadual de professores do ensino primário e profissionalizante de 1958 a 1975, trabalhando com adolescentes e jovens na área artística. Nesse período, conheceu o jovem Francisco Neves, de quem foi professora e tutora. "Francisco foi um dos seus alunos mais promissores do campo das artes" (depoimento de amiga/professora da UFRPE).

Ministrou aulas na Escola Frei Caneca/Zé Maria, onde dava aula de estamparia, desenho, tapeçaria para meninas e meninos em condições de vulnerabilidade e em situação de rua. Também lecionou na Escola Técnica do Recife, na Escola Padre Félix e na Escola Murilo Braga, entre outras. No dia 1 de março de 1960, ingressou na UFRPE como professora de ensino básico e técnico e tecnológico, ministrando aulas no curso de Licenciatura em Economia Doméstica e no Colégio Agrícola e Técnico da UFRPE, Dom Agostinho Ikas (Codai).

No departamento de Economia Doméstica (atual departamento de Ciências do Consumo), Inalda ministrou as disciplinas de Introdução à Arte; Estilos de Arte; Desenho Artístico; Decoração de Interiores e Psicodinâmica das Cores. Ela ainda foi membro efetivo da Associação dos Professores da UFRPE e diretora do Departamento de Economia Doméstica de 24 de fevereiro de 1978 até 1982, quando veio a se aposentar, conforme Portaria № 120, de 13 de setembro de 1982.

As artes e o ensino de artes levaram Inalda a conhecer o mundo. Ela realizou cursos nas mais variadas áreas das artes, no Rio de Janeiro, Estados Unidos, Jamaica, Inglaterra, entre outros lugares. Apresentamos alguns desses cursos: Artes Industriais (Rio de Janeiro, 1962); Formação de Professores de Artes Industriais (Rio de Janeiro, 1966); Treinamento Artesanal em Cerâmica (Recife, 1968); Cursos de Joias, Esculturas, Criação e Vestidos, Pesquisa Têxtil, Metal (New Mexico, Estados Unidos, 1978); Pesquisa e Avaliação (Jamaica, 1979); Aquarela e Pastel (Londres, Inglaterra, 1991-1992); Arte Barroca (Minas Gerais e Bahia, 2003) (ATEMPORAL, 2011). 


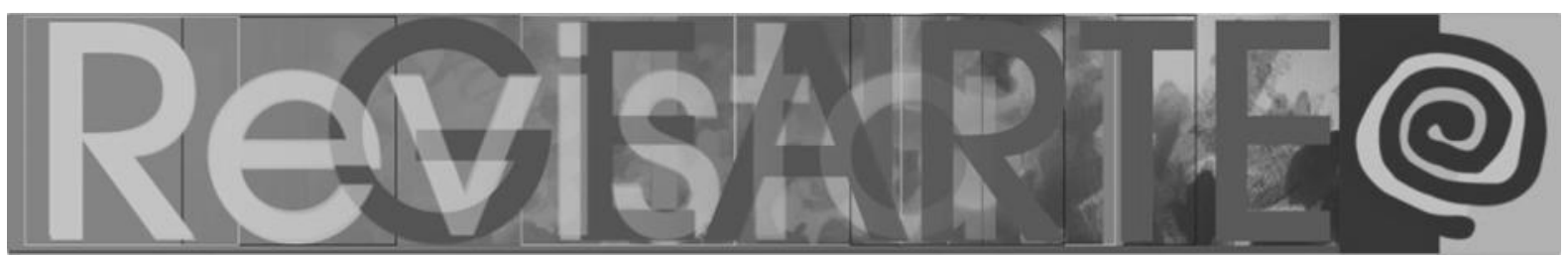

Vale a pena destacar que a época em que Inalda iniciou seus estudos é marcada pelo forte conservadorismo da sociedade pernambucana. As mulheres eram estimuladas a fazer artes como forma de se preparem para serem "donas de casa". Além disso, dizer-se artista era algo que tinha uma certa repercussão, pois carregava estereótipos não muito aceitos pela sociedade (BARBOSA, 2009). De acordo com os depoimentos da família, Inalda foi uma mulher de vanguarda que sabia se colocar no mundo, perseguia seus objetivos de forma obstinada e tranquila. Além disso, ela não percebia a arte como profissão. A arte em sua vida era um hobbye não tinha como prioridade a comercialização de suas obras (AABB, 1963). Talvez por esse motivo ela não tenha investido esforços para a autopromoção e divulgação de seu trabalho artístico. Assim, justifica-se o fato de não ser amplamente conhecida pela sociedade de modo geral e pela universidade onde atuou. Contudo, seu desenvolvimento nessa área era destacado, mesmo no início de sua carreira, como pode-se perceber pela reportagem da revista do Banco do Brasil, em 1963:

Artistas são sempre tema. Mas Inalda é um super-tema. É um impacto conhecê-la. Moça de simplicidade invulnerável. Artista completa. Completa porque sabe ser artista. Tem a mais autêntica alma de artista. Não superestima as suas obras. Vem resistindo a insinuante proposta para a comercialização de sua arte. Prefere viver de sua profissão "Dá duro" em múltiplas atividades. É professora primária na Escola Modelo e ensina desenho na Universidade Rural. É tão modesta que coletar dados sobre sua vida foi um sacrifício. Felizmente Corbiniano Lins lá estava. Ajuda inestimável. Inalda Xavier (IX) tem uma bagagem impressionante. Há em sua casa quartos super-lotados. Já fez trabalhos perfeitíssimos utilizando matéria-prima regional, tais como: palha de milho, "barba de bode", vime, caroá, piaçava, etc. Em cestaria Inalda dá "show". Em cerâmica não fica atrás. Na pintura encanta. Há em todos os seus trabalhos um quê fascinante. Costuma trabalhar também em madeira. Faz xilogravuras com perfeição admirável. Traços marcantes. Fez, há pouco tempo, uma exposição individual na Galeria Rozenblit, desta cidade. Teve êxito. Inalda Xavier da Silva, que é o seu nome completo, é, ante de todo, uma moça organizada. Tem catalogado tudo quanto the interessa ou lhe diz respeito. Em álbuns preciosos ensina certas formas difíceis de tecer um tapete, de fazer uma bolsa para senhora, nos seus mínimos detalhes (AABB, 1963, p. 40-44).

O depoimento do grande artista Corbiniano Lins, na mesma reportagem à revista do Banco do Brasil, também atesta a qualidade do trabalho de Inalda: 


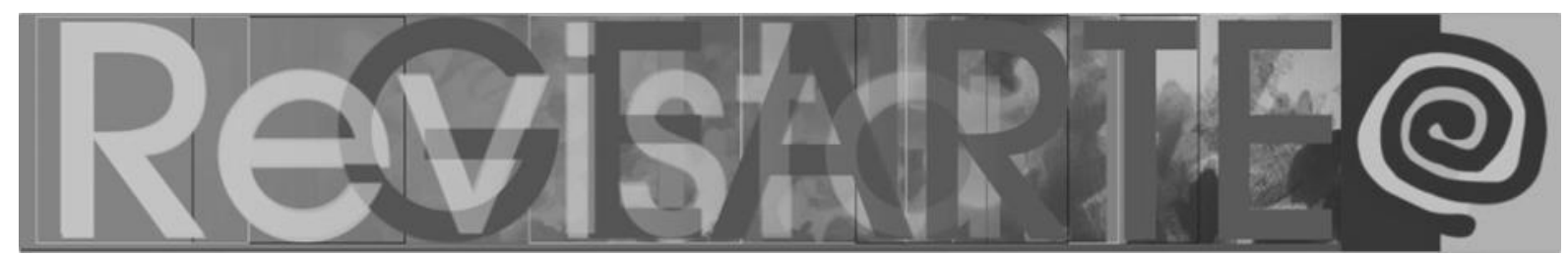

Inalda é um valor nativo da nova geração de artistas pernambucanos. Conseguiu bolsa de estudos através do Inep, e, no Rio de Janeiro, especializou-se nas técnicas que hoje utiliza, tendo estudado desenho com o nipônico Dink Kim. Entre outros idiomas com os quais é identificada, ela estuda alemão e pretende visitar o grande país germânico dentro em breve. Em 1961 conquistou o primeiro prêmio em Salão de Arte patrocinado pela Escola de Belas Artes. Concorrendo com outros artistas, inclusive do Sul do país, recebeu o segundo prêmio de gravura no Salão Oficial de Pernambuco (AABB, 1963, p. 45).

A artista participou dos principais grupos e movimentos da história da arte de Pernambuco. Participou da Sociedade de Arte Moderna do Recife, atuando principalmente através do Clube de Gravuras; foi membro da Associação de Artistas Plásticos Profissionais de Pernambuco (BRITO NETO, 2016); do Movimento de Cultura Popular e da Oficina Guaianases de Gravura, da qual foi sócia fundadora (ATEMPORAL, 2011). Na pesquisa realizada, não foi possível identificar se Inalda participou ou frequentou o Atelier Coletivo, grupo criado no Recife em 1952.

Inalda era uma artista multifacetada, cujo trabalho incorpora diferentes técnicas e materiais. Confeccionou bonecas de pano, com roupas artisticamente elaboradas; criou joias; produziu esculturas em papel machê; tapeçaria; esculturas em cerâmica; xilogravura; pintura à mão com bico de pena e litogravura, estilo em que mais se destacava.

\begin{abstract}
A trajetória de sua vida de desenhista, pintora, ceramista, gravurista em pedra, metal e madeira, designer e executora de joias, como criadora constantemente inquieta de objetos artesanais ou de arte, ora reflete a sua paciência de artes à medieval, errante nos espaços de um mundo tecnológico, ora revela a sua inspiração tanto lírica, como dramática, sobre as pessoas e as suas condições de vida (CORBINIANO, 2011, apud ATEMPORAL, 2011, p. 4).
\end{abstract}

Inalda chegou a dividir um ateliê com a artista Ana Gonçalves, no bairro do Pina. De acordo com Ribemboim e Souza (2014) manteve um ateliê no pátio de Santa Cruz e realizou exposições individuais e coletivas em várias partes do mundo. Destacamos a participação da artista em exposição organizada por Wilton de Souza, em 1962; por Dom Helder Câmara, em 1963; por Helio Grimberg, 1965; 


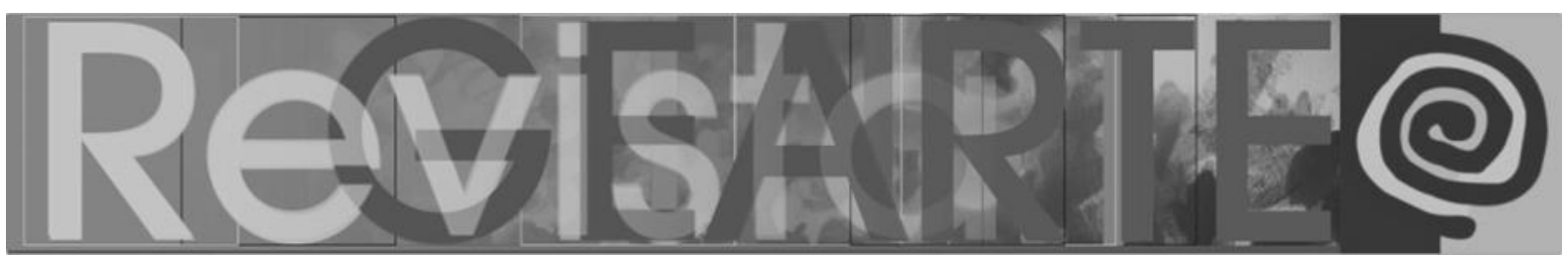

por Sebastião Barbosa, em 2002. Ainda podemos destacar as exposições internacionais, em países como Estados Unidos, Espanha, França, Inglaterra, Alemanha, Japão, Romênia e Grécia.

A seguir elencamos, em ordem cronológica, as exposições individuais e coletivas nacionais e internacionais da artista.

Exposições individuais:

1962 - Exposição de xilogravuras na Galeria de Artes Rozemblit, Recife, Pernambuco, patrocinador Wilton de Souza;

1965 - Exposição de xilogravuras na Associação Atlética do Banco do Brasil, Recife, Pernambuco;

1970 - Exposição de joias em prata e bronze, New Mexico State University, New Mexico, Estados Unidos;

1989 - Exposição de xilogravuras na Galeria Jutta Schnaitmann, Bocholt, Alemanha;

2005 - Exposição Los ojos de la vida na Galeria La Carboneria, Sevilha, Espanha; 2008 - Exposição Lúdico do ser no Atelier Ana Lúcia Gonçalves, Recife, Pernambuco;

- Exposição Atemporal na galeria UFFICI, Recife, Pernambuco.

Exposições coletivas:

1963 - Salão de Arte Contemporânea no Museu de Arte de São Paulo (MASP), São Paulo;

1963 - III Feira de Arte. Rio de Janeiro, patrocinador: D. Helder Câmara;

1965 - Galeria O Sobrado, patrocinador Helio Grimberg. São Paulo;

MELO, Énery Gislayne de Sousa; VILA NOVA, Julio Cesar Fernandes; PATELLO, Vera Conceição Alves; MONTEIRO, 82 Josimar Alves. A importância de Inalda Xavier para a constituição do patrimônio das artes visuais da UFRPE.

Revista GEARTE, Porto Alegre, v. 8, n. 1, p. 66-92, jan./abr. 2021.

Disponível em: http://seer.ufrgs.br/gearte 


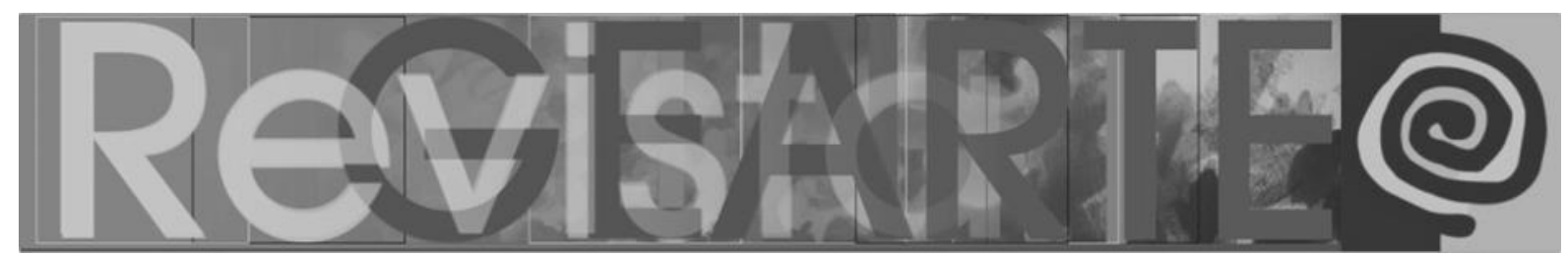

1966 - Exposição de tapeçaria, Casa Holanda, Recife, Pernambuco;

1977 - Exposição Nu artístico, Museu de Arte Contemporânea de Olinda, Pernambuco;

1979 - Guaianases II, Rio de Janeiro;

1980 - Guaianases III, Curitiba, Paraná;

1982 e 1987 - Mostra anual de litografia, Curitiba, Paraná;

1989 e 1995 - II e IV Salão Nacional de Arte Religiosa - PUC, Curitiba, Paraná;

1991 - Mostra de desenhos da Galeria Rodrigues, Recife, Pernambuco;

2001 - Exposição de litogravuras Diálogo com a pedra, UFPE, Recife, Pernambuco;

2002 - Exposição no Mar Hotel, Recife, Pernambuco, patrocinador Sebastião Barbosa;

2009 - Alex: 60 anos de Jornalismo, Museu do Estado de Pernambuco;

2009 - Pedra papel na Torre Malakoff, Recife, Pernambuco;

2009, 2010, 2011, 1012, 2013, 2014, 2015, 2016 e 2017 - Artes do IMIP - Instituto Cultural Banco Real, Recife, Pernambuco;

2014 - Exposição Oficina Guaianases de Gravuras: o olhar feminino. Museu da Abolição, Recife, Pernambuco;

2016 - Coleção Abelardo Rodrigues de Papel do Museu de Arte Contemporânea de Pernambuco, Recife, Pernambuco. 


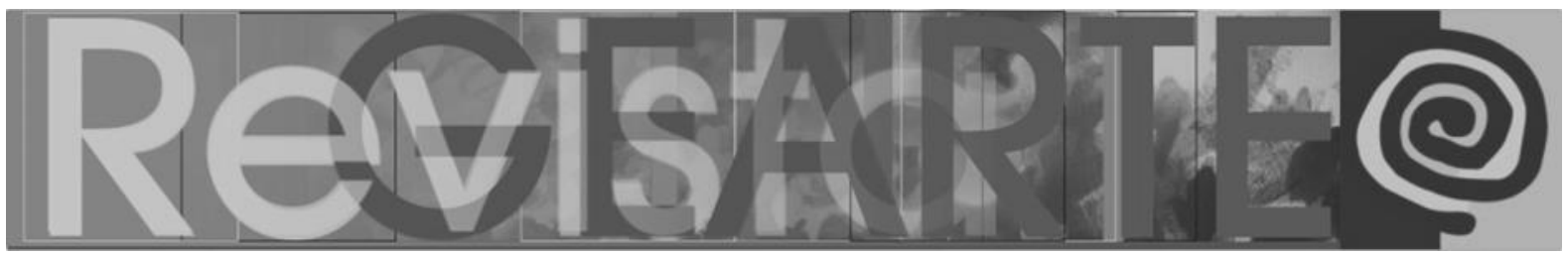

Exposições internacionais coletivas:

1989 - Litogravura, Bocholt, Alemanha;

1990 - Brasil Phaseli, Savannah, Geórgia, Estados Unidos;

1994 - III Trienal Mundiale d'Estampes Petit Format, Chamaliers, França;

1995 - The 18th International Independent Exhibition of Prints, Japão;

1995 - Exposição Internacional de Gravuras, Salão Carbonarl, Museum Floean Baia Mare, Romênia;

1997 - The 19th International Independent Exhibition of Prints, Japão; Trienal Internacional de Arte Gráfica, República da Macedônia;

1998 - Exposição Internacional de Desenhos, Hachioji, Japão;

1999 - Triênio Internacional de Gravura, Egito;

2003 - 3sd Egyption Ministry of Culture National, Center of Fine Arts Cafour; 4ํㅜㄴ Triênio Internacional de Gravura, Museu de Arte em Alexandria, Egito.

Ao longo de sua carreira, Inalda teve inúmeros trabalhos premiados ou reconhecidos, dos quais elencamos alguns exemplos abaixo, também em ordem cronológica:

1961 - 20ํlugar no XX Salão de Pintura de Pernambuco (prêmio recebido por xilogravura);

1961 - Prêmio Fiat Lux de trabalho artesanal da Fiat Lux Companhia de Fósforos; 1962 - 1ํo Lugar no XXI Salão de Pintura de Pernambuco (prêmio recebido por xilogravura);

1962 - Menção honrosa no XXII Salão de Pintura de Pernambuco;

MELO, Énery Gislayne de Sousa; VILA NOVA, Julio Cesar Fernandes; PATELLO, Vera Conceição Alves; MONTEIRO,

84 Josimar Alves. A importância de Inalda Xavier para a constituição do patrimônio das artes visuais da UFRPE

Revista GEARTE, Porto Alegre, v. 8, n. 1, p. 66-92, jan./abr. 2021.

Disponível em: http://seer.ufrgs.br/gearte 


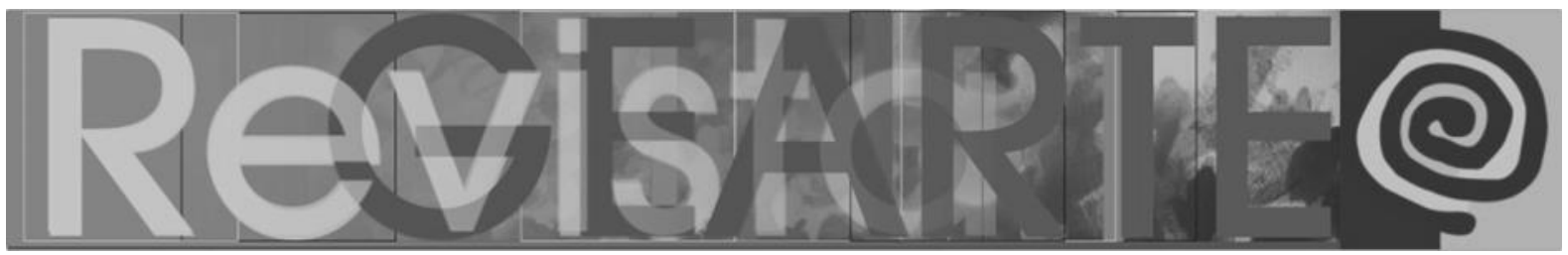

1962 - Medalha da Federation of Unesco Association in Japan;

1964 - My mother - International Exhibition and Children's Drawing Competition Sponsors - Morinagas's Society for Singing the Praises of Mother and Federation of Unesco Association Japan. Nesse evento, seus alunos foram premiados com as medalhas de ouro, prata e bronze no Japão, sendo os únicos do Brasil;

1973 - Título Greetings Honorary Citizen of Las Cruces, New Mexico, Estados Unidos;

1994 - Parchemin D’honneur ao Reconnaissance, Chamaliers, França;

2008 - Prêmio em artes plásticas na décima edição do concurso Talento da maturidade do Banco Real.

As obras de Inalda Xavier foram exibidas em diversos catálogos e guias de artes. Alguns são apresentados a seguir. Destacamos, em particular, o acervo digitalizado da Oficina Guaianases, que reúne 176 litogravuras da artista.

1980 - Imagens do Recife, Prefeitura de Recife;

2008 - Coleção História da Oficina Guaianases de Gravuras;

2011 - Olinda Arte em Toda Parte;

2012 - Anuário Pernambuco de Arte;

2014 - Anuário Pernambucano de Arte;

2016 - Ateliês Pernambucanos 1964-1982;

2016 - Acervo Educativo, Coleção Abelardo Rodrigues de Papel;

2017 - Universidade Federal de Pernambuco: patrimônio artístico em exibição. 


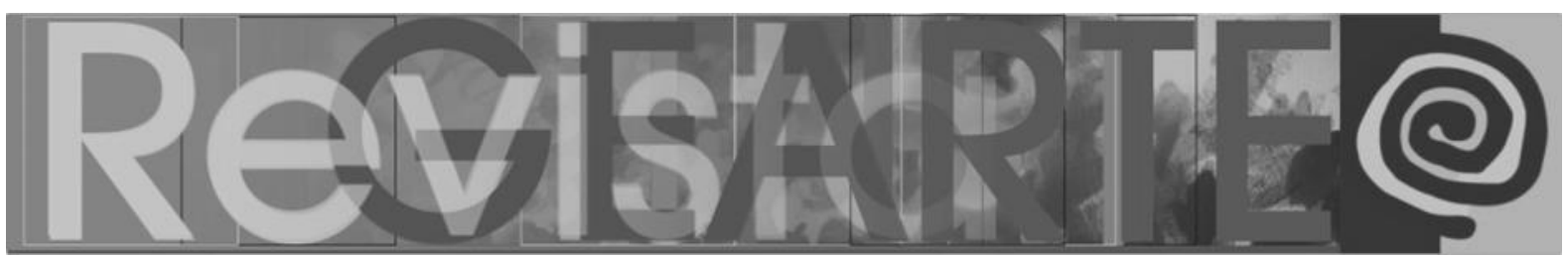

Além desses trabalhos, Inalda Xavier ilustrou as seguintes revistas e livros, como por exemplo:

1972 - Folhas secas: poesias de autoria de monsenhor Francisco Salles;

2004 - Um olhar: versos e imagens de autoria de Jiçara Martins.

\section{Influência artística de Inalda Xavier no acervo da UFRPE}

A catalogação de obras de artes visuais na UFRPE levantou 25 obras entre painéis, bustos e esculturas, produzidas por sete autores identificados: Inalda Xavier, Christina Machado, Corbiniano Lins, Francisco Neves, Laércio Dias Braga e Lula Cardoso Ayres. Foram localizadas quatro obras cuja autoria não foi possível identificar.

Entendemos que, dada a relevância de sua trajetória artística e a qualidade de sua obra, Inalda Xavier desempenhou um papel de significativa importância na constituição desse acervo, não obstante a presença de apenas um trabalho de sua autoria. Trata-se, afinal, de um trabalho grandioso em suas dimensões e em sua qualidade estética, de inegável representatividade para a instituição onde está localizado. A importância de Inalda pode ser observada também pela influência exercida por ela sobre outros artistas do grupo.

O primeiro nome que aparece, nesse sentido, é o de Corbiniano Lins. Em termos quantitativos, é ele o artista com presença mais significativa no acervo da UFRPE: quinze obras, localizadas nas proximidades ou no interior de oito prédios do campus sede da UFRPE, em Dois Irmãos. Registramos que entre as quinze obras, sete são placas de conclusão de curso. Trata-se de grande amigo e mentor de Inalda, conforme apontam os textos de apresentação dele sobre ela, coletados na pesquisa, bem como depoimentos da família da artista.

Sobre a relevância do trabalho de Inalda, Corbiniano Lins faz a seguinte análise: 


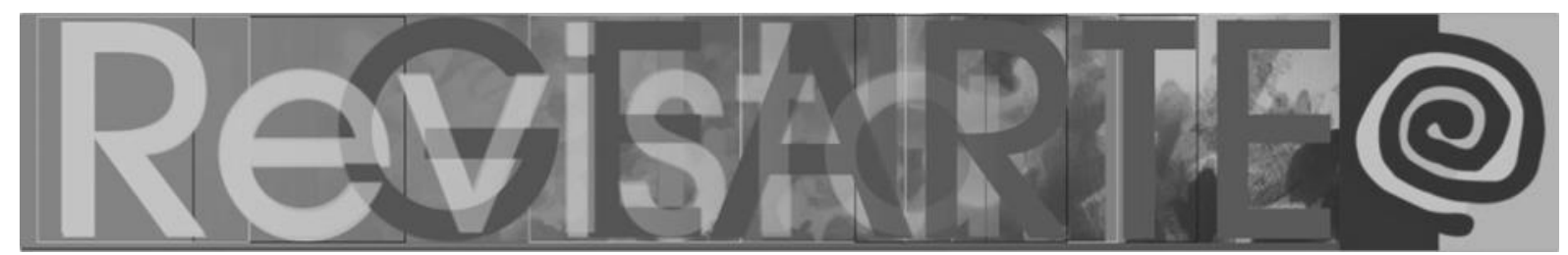

A sua inquietação interior procura extravasar na representação da pessoa humana, como um dos temas dominantes dos seus trabalhos, em que tenta comunicar a sua empatia nostálgica pelas formas plásticas da criança e do adolescente, ou pelas figuras da maternidade, tão marcantes em sua simbologia humana. A simbologia mãe-filho é forte e múltipla, nas várias formas de que se reveste, emocionalmente, no conjunto dos seus limites e das suas xilogravuras. [...] Expressa a sua preocupação de artista com as condições de vida do nordestino. Daí também a inquietação com a qualidade de vida e o sentimento da criação ou do jovem, que ela procura apresentar, através de expressões de tristeza e de solidão das crianças e adolescentes pobres, tão frequentes nas suas xilogravuras ou litogravuras. Crianças e jovens de olhos grandes e tristes, que parecem carregar o peso do sentimento do mundo, na expressão sofrida do seu rosto. Sua sensibilidade cria e recria situações humanas, na ampla galeria de tipos antropológicos, que ela descobre no dia a dia das profissões humildes dos vendedores de frutas, de pássaros e de peixes, dos barqueiros ou das mulheres do povo, que carregam nos ombros seus potes de barro. Paradoxalmente, ao lado desta galeria de tipos humanos tocados pelo sofrimento da pobreza, há também, as xilogravuras que revelam a leveza do gesto das pequenas bailarinas e dos meninos sonhadores, que vão para a mata, à procura de passarinhos, iluminado, em repentina ternura, o espaço poético recriado pela artista. O mar, os rios, os barcos parados nas margens das marés, os peixes, os pássaros, as aves simbolicamente exóticas, os gatos macios na sua impossível tranquilidade são outros temas constantes da sua galeria fantástica, em que o irreal se sobrepõe ao real (CORBINIANO, 2011, apud ATEMPORAL, 2011, p. 4).

Um dado interessante, que corrobora a importância de Inalda Xavier no contexto da produção artística da UFRPE, é o fato de a maioria dos trabalhos catalogados na universidade estar localizada no prédio em que a artista ministrava aulas, no Departamento de Ciências Domésticas (atualmente denominado Ciências do Consumo). De um total de catorze obras aí encontradas, doze são de autoria de Corbiniano Lins, uma de um autor ainda não identificado e uma de Francisco Neves, pupilo de Inalda, que fez uma carreira sólida no campo das artes plásticas.

A pesquisa identificou que, no período de atuação docente de Inalda Xavier na UFRPE, entre 1960 e 1989, a universidade teve um acréscimo de dezenove obras de artes em seu acervo. Reconhecemos aí uma evidência da sua importância como figura incentivadora da presença artística na universidade. As demais obras do acervo foram adquiridas posteriormente, sendo uma de Corbiniano Lins (em 1992); uma da artista Christina Machado (1999); e uma de Laércio Dias Braga (2010). Outras sete obras, todas de autoria de Corbiniano Lins, 


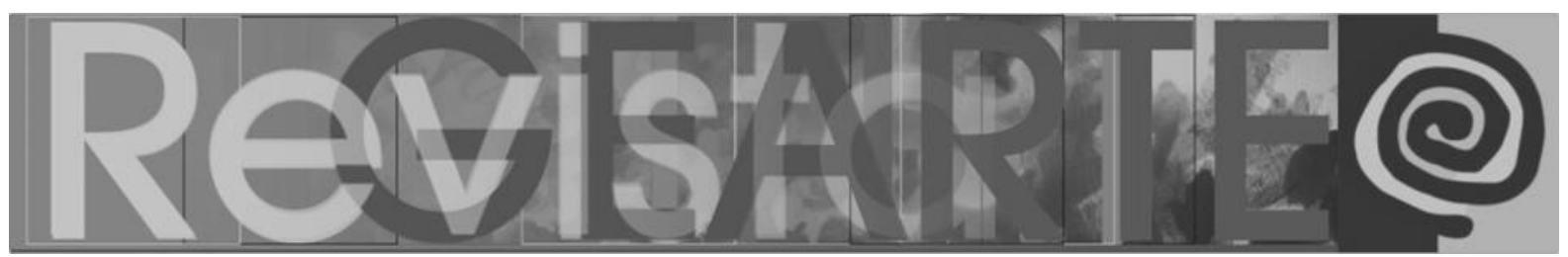

não têm o ano de produção identificado, sendo seis delas alocadas no departamento de Economia Doméstica.

Um questionamento que surgiu durante o desenvolvimento da pesquisa foi sobre a razão de Inalda Xavier ter apenas uma obra na universidade. Uma das possíveis explicações, baseada em depoimentos de familiares e de ex-alunos, é que ela era uma artista de postura discreta, que não fazia questão de se promover. Apesar da inegável qualidade de sua produção, Inalda encarava a arte como uma atividade que the permitia exercer a criatividade, sem necessariamente buscar o reconhecimento público por isso. Ela costumava dizer "que fazia artes para ela mesma". Assim, era de se esperar que ela não difundisse os seus trabalhos. Ainda sobre o painel localizado na UFRPE, de acordo com as entrevistas realizadas, é uma produção realizada por solicitação do reitor à época (1978), o senhor Humberto Carneiro, grande apreciador do trabalho da artista e professor do departamento de Agronomia.

A partir das considerações apresentadas, assinalamos que a constituição do acervo da universidade foi resultado da presença, ainda que discreta, da artista plástica e professora Inalda Xavier. Sua trajetória no cenário artístico comprova a sua importância, e o reconhecimento público como uma das melhores gravuristas do Recife pode ser constatado pelas várias premiações e publicações, e também pela imprensa pernambucana, como atesta a nota publicada pelo colunista Alex no Jornal do Comércio, no "Caderno C", de 19 de novembro de 2011.

\section{Considerações finais}

Neste trabalho, buscamos apresentar, em linhas gerais, o projeto de pesquisa "Artes visuais da UFRPE: revelações identitárias a partir do patrimônio artístico-histórico", apontando alguns de seus primeiros resultados, com enfoque sobre a figura da artista e professora Inalda Xavier. Tendo em vista que o projeto está em sua fase inicial, ainda há muito por fazer, como a pesquisa biobibliográfica 


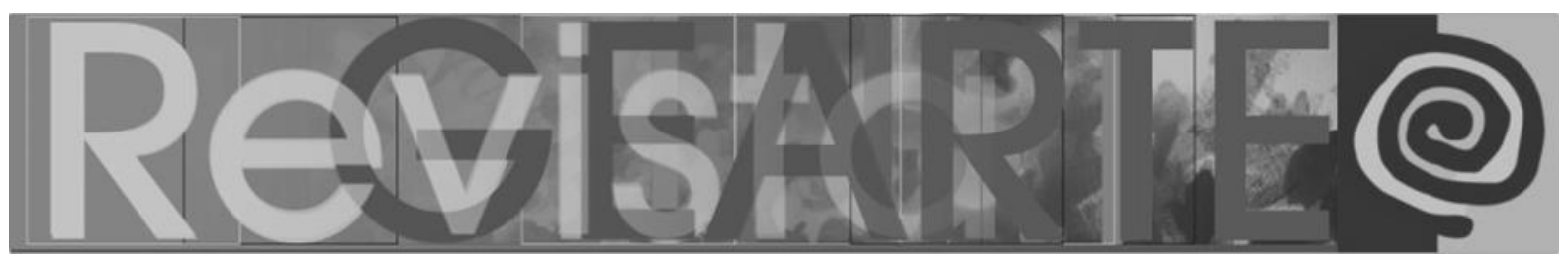

sobre os outros artistas presentes na universidade, a criação de um catálogo virtual para exposição das obras e outras formas de divulgação.

Em relação à obra de Inalda Xavier, o seu painel é um dos mais marcantes do levantamento realizado, pelas suas dimensões, pertinência temática, riqueza de detalhes e valor artístico. A obra atesta a importância de Inalda Xavier no panorama artístico de Pernambuco, e cujo trabalho teve alcance nacional e internacional. A pesquisa sobre sua trajetória permitiu reconhecer sua presença entre os grandes nomes da arte em Pernambuco, inclusive com participação em grupos que marcaram a evolução da produção artística em nosso estado, a exemplo da Sociedade de Arte Moderna, do Clube da Gravura e da Oficina Guaianases. Aí, a artista figura ao lado de nomes como Murilo La Greca, Abelardo da Hora, Lula Cardoso Ayres, Reynaldo Fonseca, Wilton de Sousa, Francisco Neves e Corbiniano Lins. Aliás, com esses dois últimos manteve uma forte amizade. Francisco Neves foi seu aluno, e Corbiniano, um dos maiores incentivadores de sua carreira artística. Atribuímos a essa proximidade um dos motivos da presença desses dois artistas no patrimônio da UFRPE.

Este trabalho se reveste de uma importância ainda maior, para o registro histórico da instituição, considerando-se o fato de que Inalda Xavier teve uma trajetória acadêmica atuando como docente da UFRPE. Acreditamos, assim, que o projeto de catalogação da produção artística da UFRPE preenche uma lacuna quanto a esse registro histórico e contribui para ampliar a compreensão da importância da universidade para a sociedade.

\section{Referências}

ACERVO EDUCATIVO. Catálogo da exposição do Museu de Arte Contemporânea. Olinda: MAC, 2016.

ANUÁRIO PERNAMBUCANO DE ARTE. Catálogo. Recife: Editora Negócios, 2012.

ANUÁRIO PERNAMBUCANO DE ARTE. Catálogo de exposição da Arte Maior Galeria. Recife: Arte Maior Galeria, 2014.

ANUÁRIO PERNAMBUCANO DE ARTE. Catálogo de exposição do Museu do Estado de Pernambuco. Recife: MEP, 2016. 


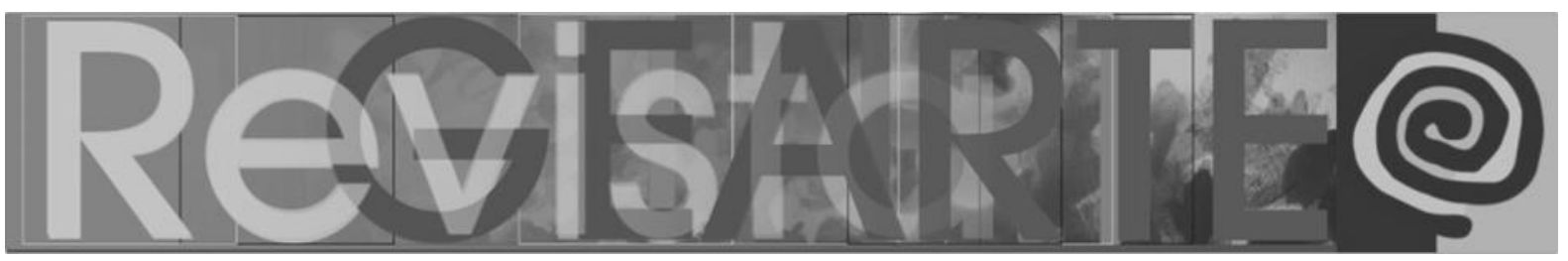

ATEMPORAL. Catálogo de exposição da galeria UFFICl. Recife: Gráfica JB, 2011.

BARBOSA, Ana Mae. A imagem no ensino da arte: anos 1980 e novos tempos. São Paulo: Perspectiva, 2009.

BERTELLO, Maria Augusta. Minimanual de pesquisa em arte. São Paulo: Perspectiva, 2004.

BELTING, Hans. O fim da história da arte. São Paulo: Cosac Naify, 2012.

BORDIEU, Pierre. O amor pela arte: os museus de arte na Europa e seu público. São Paulo: Zouk, 2003.

BRASIL. Secretaria de Educação Fundamental. Parâmetros Curriculares Nacionais: Arte. Brasília, DF: Ministério da Educação, 1998.

BAZILI, Fabiana Lopes; ZAMPERETTI, Maristani Polidori. A cultura visual na educação das artes visuais: uma pesquisa no ensino fundamental. Revista Travessias, Cascavel, v. 7, n. 1, p. 95-110, 2013.

CARDOSO, Lúcia de Fátima Padilha; SANTOS, Hassan Fellipe dos; TORRES, Niedja Ferreira dos Santos. Recife arte pública: a cidade como campo para ações educativas. In: CADENGUE, Antonio Edson; CONSTÂNCIO, Rudimar. Vida artista: diálogos entre arte/educação e filosofia. Recife: SESC Pernambuco, 2017. p. 911-917. Disponível em: http://congressoarteeducacao.sescpe. com.br/. Acesso em: 27 jun. 2019.

CARVALHO, Maria Auxiliadora; OTERO, Maria Mercedes Dias Ferreira; BARBOSA, Josefa Pereira. Acesso e preservação da coleção Oficina Guaianases de Gravuras. Informação \& Sociedade, João Pessoa, v. 16, n. 2, p. 133-137, 2006.

CHIZZOTTI, Antônio. Pesquisa em ciências humanas e sociais. São Paulo: Cortez, 2010.

CLÁUDIO, José. Memória do Atelier Coletivo/Artistas de Pernambuco/Tratos da arte de Pernambuco. Recife: Editoria CEPE, 2010.

GASPAR, Lúcia. Movimento de Cultura Popular. Fundação Joaquim Nabuco, Recife, 2009. Disponível em: http://basilio.fundaj.gov.br/pesquisaescolar/. Acesso em: 30 maio 2019.

MARTINS, Conceição; LEITÃO, Maria do Rosário de Fátima de. Prédio da reitoria da UFRPE: resgate histórico 1935-2009. Recife: Editora Universitária da UFRPE, 2009.

MARTINS, Jiçara. Um olhar... versos e imagens. Belo Horizonte: Mazza, 2004.

BRITO NETO, José Bezerra de. Carteira de artista: memórias da Associação de Artistas Plásticos de Pernambuco (1968 - 1970). In: ENCONTRO NACIONAL DE HISTÓRIA ORAL, 13., 2016, Porto Alegre. Anais [...]. Porto Alegre: Universidade do Rio Grande do Sul, 2016.

OLINDA. Catálogo Olinda arte em toda parte. Olinda: Prefeitura de Olinda, 2011.

OTERO, Maria Mercedes Dias Ferreira (org.). Coleção histórica da Oficina Guaianases de gravuras. Recife: Néctar, 2008.

RECIFE. Lei oㅜ 7.427, de 19 de outubro de 1961. Código de Urbanismo e Obras: codificação das normas de urbanismo e obras. Câmara Municipal do Recife, Recife, 1962. Disponível em: https://leismunicipais.com.br/legislacao-municipal/2880/leis-de-recife. Acesso em: 30 maio 2019.

RECIFE. Lei no 16.292, de 29 de janeiro de 1997. Regula as atividades de edificações e instalações no Município do Recife. Diário Oficial do Munícipio, Recife, 31 jan. 1997. Disponível em: https://leismunicipais.com.br/legislacao-municipal/2880/leis-de-recife. Acesso em: 30 maio 2019.

RECIFE. Imagens do Recife. Recife: Prefeitura do Recife, 1980.

AABB. Um estímulo à cultura em favor do progresso. Revista $A A B B$, Recife, v. 3, n. 9, 1963.

MELO, Énery Gislayne de Sousa; VILA NOVA, Julio Cesar Fernandes; PATELLO, Vera Conceição Alves; MONTEIRO, 


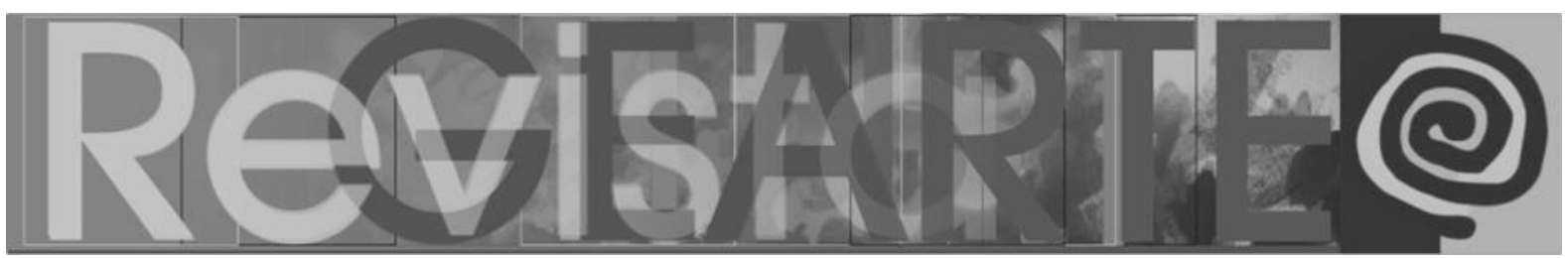

RIBEMBOIM, Jacques, SOUZA, Wilton. Boa Vista: berço das artes plásticas pernambucanas. Olinda: Babbecco, 2014.

RIBEIRO, Sousa Emanuela; ARAÚJO, Bruno de Melo; NEWTON JUNIOR, Carlos. Catálogo da exposição Universidade Federal de Pernambuco: patrimônio artístico em exibição. Recife: Editora UFPE, 2017.

SALLES, Monsenhor Francisco. Folhas secas. Recife: Editora da Academia Pernambucana de Letras, 1972.

SOUZA, Francisco de Sousa. O Movimento de Cultura Popular do Recife 1959-1964. 2014. Dissertação (Mestrado em História) - Faculdade de Filosofia, Letras e Ciências Humanas, Universidade de São Paulo, São Paulo, 2014.

THIOLLENT. Michel. Metodologia da pesquisa-ação. 3. ed. São Paulo: Cortez, 1988.

UFRPE. Projeto pedagógico curricular do curso de Licenciatura em Artes Visuais com ênfase em digitais. Recife: UFRPE, 2019.

UFRPE. Projeto pedagógico curricular do curso de Especialização em Artes e Tecnologias. Recife: UFRPE, 2018.

\section{Énery Gislaine de Sousa Melo}

Doutora e Mestra em Ensino das Ciências com ênfase em Física. Licenciada em Física pela Universidade Federal Rural de Pernambuco. Atua no ensino de Artes e de Física, e desenvolve atividades de ensino e de popularização da astronomia por meio do projeto Desvendando o Céu Austral. Integra o grupo de pesquisa em Ensino de Ciências e Contemporaneidade (GECIC), trabalhando principalmente nos seguintes temas: uso do teatro no ensino de ciências, aproximações entre a física e as artes, formação de professores, história e filosofia da ciência, representações sociais de ciências e metodologias do ensino de física. Coordenadora do projeto Artes da UFRPE.

ORCID: https://orcid.org/0000-0003-4209-9072

E-mail: enerygmelo@gmail.com

Currículo: http://lattes.cnpq.br/2653085378828449

\section{Julio Cesar Fernandes Vila Nova}

Doutor em Letras pela Universidade Federal de Pernambuco (UFPE). Professor Adjunto 2 do Departamento de Letras da Universidade Federal Rural de Pernambuco UFRPE, desde 2009. Tem experiência na área de linguística e ensino de línguas inglesa e portuguesa. É membro do Centro de Estudos em Educação e Linguagem (CEEL/UFPE). Atua na área de formação de professores e na área de produção cultural. Tem interesse em estudos culturais, gêneros do discurso e letramento.

ORCID: https://orcid.org/0000-0001-5186-7593

E-mail: juliovnova71@gmail.com

Currículo: http://lattes.cnpq.br/6629242832192015 


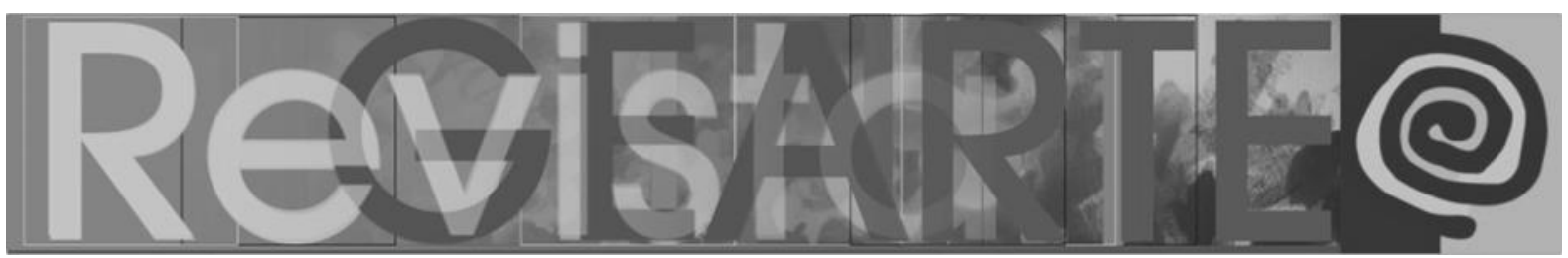

Vera Conceição Alves Patello

Graduanda do curso de Artes Visuais/Digitais da Universidade Federal Rural de Pernambuco, integrante do projeto Artes da UFRPE.

ORCID: https://orcid.org/0000-0003-4982-8354

E-mail: vera.patello@gmail.com

Currículo: http://lattes.cnpq.br/6397865588491092

\section{Josimar Alves Monteiro}

Graduando do último período do curso de Licenciatura em Artes Visuais da UFRPE. Integrante dos projetos de pesquisa e de extensão Artes da UFRPE.

ORCID: https://orcid.org/0000-0002-7632-0110

E-mail: josimar_monteiro@yahoo.com

Currículo: http://lattes.cnpq.br/6993483726509423

Recebido em 15 de abril de 2020

Aceito em 15 de outubro de 2020 